\title{
Ergonomic Aspect Analysis of Classroom's Table and Chairs Design for Vocational High School
}

\author{
Mathilda Sri Lestari \\ Universitas Veteran Bangun Nusantara \\ Sukoharjo, Indonesia \\ mathildasrilestari@yahoo.com
}

\author{
Tri Wibowo \\ Universitas Veteran Bangun Nusantara \\ Sukoharjo, Indonesia \\ Triwibowo@yahoo.com
}

\author{
Ainur Komariah \\ Universitas Veteran Bangun Nusantara \\ Sukoharjo, Indonesia \\ ainurkomariah@yahoo.com
}

\begin{abstract}
The purpose of this study was to obtain an ergonomic aspect analysis on the design of classrom's tables and chairs for high school and vocational high school. The study was conducted at SMK Veteran 1 Sukoharjo, with research subjects of 30 students aged 16 years to 18 years. The data that is needed in this study are anthropometric data of 12 dimensions of the subject's body in a sitting position. These data are : popliteal height, popliteal buttocks, hip width, shoulder width, shoulder height, height of the upper back, elbows sitting, elbows to fingers, length of the buttock to knees, height of the ankles, range of hands, and thighs. Research stages include: goal setting, data collection, data processing, and analysis. Data collection was carried out by measuring anthropometric data. Data processing was carried out by testing data uniformity, testing data adequacy, calculating percentile of data, and designing chair and table based on anthropometric data. Analysis was carried out on data collected and on ergonomic aspects of table and chair designs. From the results of preliminary observations, it is known that $80 \%$ of students stated that the existing tables and chairs are not comfortable to use. This is what underlies the need for redesign. From the results of the calculation and analysis, it is concluded that the width of the sitting mat needs to be added $2 \mathrm{~cm}$, the length of the backrest need to be added $2 \mathrm{~cm}$, the length of the seat sits need to be added $4 \mathrm{~cm}$, the length of the table needs to be added $4 \mathrm{~cm}$, the length of the drawer needs to be added $4 \mathrm{~cm}$, the width of the table needs to be added $16 \mathrm{~cm}$, drawer width needs to be added by $16 \mathrm{~cm}$, and the table height needs to be reduced by $9 \mathrm{~cm}$.
\end{abstract}

Keywords- classroom's table and chair design, ergonomic aspect, SMA/SMK.

\section{INTRODUCTION}

The facilities and infrastructure of the study room / classroom will be very supportive in the teaching and learning process. Some things that need to be considered in the study room / classroom are study tables and chairs, lighting, temperature, lay out, blackboard, projector distance with chair tables, and others. An ergonomic study room will certainly greatly affect the comfort of students in learning or conducting learning process activities. Ergonomics principles have not yet been applied in designing study rooms with supporting devices, both in elementary school, junior high school, high school, and university.

Lecture chairs need to be adjusted and designed with anthropometry to provide convenience and comfort for users, design college chairs using the 5\% and $95 \%$ percentile range, based on student anthropometric analysis and consideration of several opinions obtained designing a more comfortable and ergonomic lecture chair [3].
According to the recommended size so that the table height for writing and reading in a sitting position for women is between 70-74 $\mathrm{cm}$ and for men between 74-78 $\mathrm{cm}[1]$. Whereas for activities that often use the eyes, hands and arms, the work area should be at $0-15 \mathrm{~cm}$ above the elbow height.

The average student learning outcomes in the learning process of human physiology, namely the conversion of conditions from static to dynamic conditions increased from average 6.5 to 7.0 is the result of participatory ergonomics [5].

Teachers and students often do not / less pay attention to the seat / chair used. Seating plays a very important role, especially for those who do activities in a sitting position. Examples of activities carried out in a sitting position are students or students who are attending the teaching and learning process in class. Ergonomic seats must have minimum requirements, namely having legs, armrests, waistrests and backrests s[2].

Based on a survey to several schools at the Elementary School, Junior High School and Senior High School levels in Sukoharjo and also private schools it is known that the existing class chairs have the same size, shape and material. The class tables and chairs are used by students who are different from each other in terms of age, sex and body posture. With this difference, not all students feel comfortable using the chair table.

In order for the seat to be comfortable to wear when studying, the measurements must be adjusted to the user's anthropometry. To design a classroom chair, it is necessary to standardize the anthropometric measurements of Indonesians. If the standard sizes are not available, anthropometry can be measured for students who will use the seat.In addition to chairs, a study desk is also needed in accordance with the students' anthropometric data. Study table is a table used as a base during learning activities. If the study table is too high, the shoulder will be raised more often when writing or putting a hand on the table and if it is too low, the body posture will be bent when writing. Such an attitude can result in back or back pain and pain in the neck and shoulder muscles.

Facilities and infrastructure in SMK Veteran 1 Sukoharjo, especially tables and chairs for students have sizes and shapes that are not uniform, and can be said to be not ergonomic. This is due to the history of the 
establishment of SMK Veteran 1 Sukoharjo which uses buildings and facilities originating from other former institutions. This is undeniable because, it will require relatively much financing when SMK Veteran 1 Sukoharjo must immediately replace facilities and infrastructure and various other needs including the addition of new buildings and so on.

The posture of the students at SMK Veteran 1 Sukoharjo with an age limit between 16-18 years is also diverse, some are thin, fat, short and tall. Different body postures will cause a different sense of learning comfort. This causes some students to experience complaints in the body, especially in the neck, hands, feet, back, waist, elbows and knees.

\section{METHODS}

In this study the data needed is data from student statements obtained through a questionnaire consisting of several questions to support the need to redesign the classroom chair, table and also body dimension data from students of SMK Veteran 1 Sukoharjo. Data on body dimensions and their designation as in table 1. This data is obtained by measuring directly to 30 students with an age limit of 16 years to 18 years.

Table 1. Data on Student Body Dimensions in SMK Veteran 1 Sukoharjo.

\begin{tabular}{|c|c|c|}
\hline Products & $\begin{array}{l}\text { Anthropometri } \\
\text { c Data }\end{array}$ & Purpose \\
\hline \multirow[t]{2}{*}{ Chair } & $\begin{array}{ll}\text { - } & \text { Polipteal } \\
& \text { Height (TP) } \\
\text { - } & \text { Popliteal } \\
& \text { buttocks (PP) } \\
\text { - } & \text { Hip width } \\
& \text { (LP) } \\
- & \text { Shoulder } \\
& \text { width (LB) }\end{array}$ & $\begin{array}{l}\text { - To determine the height of the seat's } \\
\text { seat surface } \\
\text { - To determine the length of the seat } \\
\text { sits } \\
\text { - To determine the width of the seat } \\
\text { sits } \\
\text { - To determine the length of the chair } \\
\text { back }\end{array}$ \\
\hline & $\begin{array}{ll}\text { - } & \text { Sitting } \\
& \text { Shoulder } \\
& \text { Height (TBD) } \\
\text { - } & \text { Upper Back } \\
& \text { Height (TPA) }\end{array}$ & $\begin{array}{l}\text { - To determine the height of the seat } \\
\text { back }\end{array}$ \\
\hline \multirow[t]{5}{*}{ Table } & $\begin{array}{ll}\text { - } & \text { Polipteal } \\
& \text { Height (TP) } \\
\text { - } & \text { High Elbow } \\
& \text { Sitting } \\
& \text { (TSD) }\end{array}$ & $\begin{array}{l}\text { - To determine the height of the table } \\
\text { surface }\end{array}$ \\
\hline & $\begin{array}{l}\text { - Buttock to } \\
\text { Knee Length } \\
\text { (PBL) }\end{array}$ & $\begin{array}{l}\text {-To determine the distance between } \\
\text { the legs }\end{array}$ \\
\hline & $\begin{array}{l}\text { - Eye Height } \\
\text { (TMK) }\end{array}$ & $\begin{array}{l}\text { - To determine the height of the } \\
\text { footrest }\end{array}$ \\
\hline & $\begin{array}{l}\text { - Elbow to } \\
\text { Finger Length } \\
\text { (PSJ) }\end{array}$ & - To determine the length of the table \\
\hline & $\begin{array}{l}\text { - Seated Hand } \\
\text { Range (JTD) }\end{array}$ & - To determine the width of the table \\
\hline
\end{tabular}

Anthropometric data from measurements of body dimensions, then processed with the following calculations:

\section{Data Uniformity Test}

To find out the distribution of data obtained, is there still data in the control limit or has it been outside the control limit (out of control).

2. Data Adequacy Test

It is done to find out whether the anthropometric data collected in each measured body dimension are enough or not. In this study, the $95 \%$ confidence level and 5\% degree of accuracy were used. This means that $95 \%$ of the sample taken, the deviation will not be more than $5 \%$.

\section{Calculation of Percentile Value}

Percentile calculation is done by dividing data in population segments. This concept is used as a basis for consideration of giving a certain value as a measure of a dimension, considering that a design should be utilized by the user as much as possible, so that parts of the population that cannot use the design as small as possible.

\section{A. Data collection and calculation}

The results of the questionnaires and body dimension measurements are as in table 2 and table 3 .

Table 2 Results of Questionnaires for Students Used as Respondents

\begin{tabular}{|c|c|c|c|c|c|c|}
\hline \multirow{2}{*}{ No } & \multirow{2}{*}{ QuestionnairesData } & \multicolumn{5}{|c|}{ Number of students who stated } \\
\hline & & SA & A & $\mathrm{D}$ & SD & Amount \\
\hline 1 & Sitting position & & 9 & 18 & 3 & 30 \\
\hline 2 & Seat shape & 3 & 15 & 9 & 3 & 30 \\
\hline 3 & Seat height & 1 & 15 & 12 & 2 & 30 \\
\hline 4 & Backrest & 1 & 18 & 9 & 2 & 30 \\
\hline 5 & Seating length & & 12 & 18 & & 30 \\
\hline 6 & Seating width & 3 & 13 & 12 & 2 & 30 \\
\hline 7 & $\begin{array}{l}\text { The width of the } \\
\text { backrest }\end{array}$ & 3 & 15 & 11 & 1 & 30 \\
\hline 8 & Table width & 1 & 10 & 18 & 1 & 30 \\
\hline 9 & Table height & 1 & 13 & 15 & 1 & 30 \\
\hline 10 & Table length & & 9 & 18 & 3 & 30 \\
\hline 11 & Table shape & 3 & 18 & 8 & 1 & 30 \\
\hline 12 & $\begin{array}{l}\text { Environmental } \\
\text { conditions from } \\
\text { lighting factors }\end{array}$ & 3 & 15 & 11 & 1 & 30 \\
\hline 13 & $\begin{array}{l}\text { Environmental } \\
\text { conditions of } \\
\text { temperature factors in } \\
\text { class }\end{array}$ & 2 & 17 & 9 & 2 & 30 \\
\hline 14 & $\begin{array}{l}\text { Comfort if studying } \\
\text { long }\end{array}$ & 1 & 7 & 19 & 3 & 30 \\
\hline 15 & $\begin{array}{l}\text { Need to redesign the } \\
\text { table and chairs }\end{array}$ & 3 & 21 & 5 & 1 & 30 \\
\hline
\end{tabular}

Having obtained the anthropometric data, then performs uniformity test data and test the adequacy of the data. The results of the data uniformity test and data adequacy test can be seen in Tables 4 and 5. And the calculation of percentiles is as shown in table 7 . 
B. Analysis and determination of chair dimensions.

1. Determine the height of the seat.

To determine the height of the seat mat the anthropometric data used is the $95 \%$ popliteal height data because the chair is too high causing the user to feel discomfort. Based on the measurement results of $44 \mathrm{~cm}$.

2. Determine the length of the seat base

Determine the length of the seat base by using data distance from folding the knee to the butt (Politeal butt) 5\%. Based on the measurement results, namely: $41 \mathrm{~cm}$.

Table 3 Results of Conversion of Questionnaires in the Form of Percentage of Students

\begin{tabular}{|c|c|c|c|c|c|c|}
\hline \multirow[t]{2}{*}{ No } & \multirow[t]{2}{*}{ QuestionnairesData } & \multicolumn{4}{|c|}{$\begin{array}{c}\text { Number of students who } \\
\text { stated }\end{array}$} & \multirow[t]{2}{*}{$\begin{array}{l}\text { Am } \\
\text { ount } \\
(\%)\end{array}$} \\
\hline & & SA & $\mathrm{A}$ & $\mathrm{D}$ & SD & \\
\hline 1 & Sitting position & & 30 & 60 & 10 & 100 \\
\hline 2 & Seat shape & 10 & 50 & 30 & 10 & 100 \\
\hline 3 & Seat height & 3.3 & 50 & 40 & 6,7 & 100 \\
\hline 4 & Backrest & 3,3 & 60 & 30 & 6,6 & 100 \\
\hline 5 & Seating length & & 40 & 60 & & 100 \\
\hline 6 & Seating width & 10 & 43,3 & 40 & 6,7 & 100 \\
\hline 7 & $\begin{array}{l}\text { The width of the } \\
\text { backrest }\end{array}$ & 10 & 50 & 36,7 & 3,3 & 100 \\
\hline 8 & Table width & 3,3 & 33,3 & 60 & 3,3 & 100 \\
\hline 9 & Table height & 3,3 & 43,3 & 50 & 3,3 & 100 \\
\hline 10 & Table length & & 30 & 60 & 10 & 100 \\
\hline 11 & Table shape & 10 & 60 & 26,7 & 3,3 & 100 \\
\hline 12 & $\begin{array}{l}\text { Environmental } \\
\text { conditions from } \\
\text { lighting factors }\end{array}$ & 10 & 50 & 36,7 & 3,3 & 100 \\
\hline 13 & $\begin{array}{l}\text { Environmental } \\
\text { conditions of } \\
\text { temperature factors } \\
\text { in class }\end{array}$ & 6,6 & 56,7 & 30 & 6,7 & 100 \\
\hline 14 & $\begin{array}{l}\text { Comfort if studying } \\
\text { long }\end{array}$ & 3,3 & 23,3 & 63,3 & 10 & 100 \\
\hline 15 & $\begin{array}{l}\text { Need to redesign the } \\
\text { table and chairs }\end{array}$ & 10 & 70 & 16,7 & 3,3 & 100 \\
\hline
\end{tabular}

Table 4 Measurement of Anthropometric Data (size in $\mathrm{cm})$

\begin{tabular}{clc}
\hline No & \multicolumn{1}{c}{ Data Anthropometry } & Average \\
\hline 1 & High Popliteal & 41,53 \\
2 & Poplipteal Butt & 44,57 \\
3 & Width Hip & 33,77 \\
4 & Shoulder Width & 39,33 \\
5 & Height Seated Seat & 51,47 \\
6 & High Back Up & 38,23 \\
7 & High Elbow Sitting & 21,63 \\
8 & Elbow Length to finger & 49,37 \\
9 & Length of Buttock to Knee & 54,03 \\
10 & Foot Height & 6,67 \\
11 & Outside Seating Range & 70,27 \\
12 & Thick Thigh & 12,63 \\
\hline
\end{tabular}

3. Determine the width of the seat

Based on the results of hip width measurement using $95 \%$ percentile and plus 5 tolerance, the width of the sitting base is $44 \mathrm{~cm}$.

4. Determine the height of the backrest

When learning students do not lean too much, the lower percentile $(5 \%)$ is used. To determine the height of the backrest of anthropomic data used is the height dimension of the upper back (TPA). The measurement result is $36 \mathrm{~cm}$.

5. Determine the length of the back rest

To determine the length of the backrest, the anthropometric data used is the dimension of shoulder width (LB) $95 \%$ percentile. This is so that students who have a long shoulder width can feel comfortable while leaning, while those who have a smaller shoulder width will still feel comfortable while using the backrest. Based on the measurement results, it can be seen that the backrest length is $41.37 \sim 42 \mathrm{~cm}$

Table 5. Data Uniformity Test Results

\begin{tabular}{|c|c|c|c|c|c|c|}
\hline No. & $\begin{array}{c}\text { Anthropo } \\
\text { metric } \\
\text { Data }\end{array}$ & BKA & $\mathrm{BKB}$ & $\begin{array}{c}\text { Highest } \\
\text { Data }\end{array}$ & $\begin{array}{c}\text { Lowest } \\
\text { Data }\end{array}$ & Remarks \\
\hline 1 & $\begin{array}{l}\text { High } \\
\text { Popliteal }\end{array}$ & 45.21 & 37.86 & 44 & 39 & $\begin{array}{c}\text { Data } \\
\text { Seragam }\end{array}$ \\
\hline 2 & $\begin{array}{l}\text { Popliptea } \\
1 \text { Butt }\end{array}$ & 51.90 & 37.23 & 50 & 41 & $\begin{array}{c}\text { Data } \\
\text { Seragam }\end{array}$ \\
\hline 3 & $\begin{array}{l}\text { Width } \\
\text { Hip }\end{array}$ & 42.24 & 25.29 & 38 & 29 & $\begin{array}{c}\text { Data } \\
\text { Seragam }\end{array}$ \\
\hline 4 & $\begin{array}{l}\text { Shoulder } \\
\text { Width }\end{array}$ & 43.06 & 35.61 & 41 & 37 & $\begin{array}{c}\text { Data } \\
\text { Seragam }\end{array}$ \\
\hline 5 & $\begin{array}{l}\text { Height } \\
\text { Seated } \\
\text { Seat }\end{array}$ & 56.37 & 46.56 & 54 & 49 & $\begin{array}{c}\text { Data } \\
\text { Seragam }\end{array}$ \\
\hline 6 & $\begin{array}{l}\text { High } \\
\text { Back Up }\end{array}$ & 42.30 & 34.16 & 41 & 36 & $\begin{array}{c}\text { Data } \\
\text { Seragam }\end{array}$ \\
\hline 7 & $\begin{array}{l}\text { High } \\
\text { Elbow } \\
\text { Sitting } \\
\text { Elbow }\end{array}$ & 26.77 & 16.50 & 25 & 19 & $\begin{array}{c}\text { Data } \\
\text { Seragam }\end{array}$ \\
\hline 8 & $\begin{array}{l}\text { Length to } \\
\text { finger }\end{array}$ & 62.61 & 36.13 & 57 & 41 & $\begin{array}{c}\text { Data } \\
\text { Seragam }\end{array}$ \\
\hline 9 & $\begin{array}{l}\text { Length of } \\
\text { Buttock } \\
\text { to Knee }\end{array}$ & 65.22 & 42.85 & 62 & 48 & $\begin{array}{c}\text { Data } \\
\text { Seragam }\end{array}$ \\
\hline 10 & $\begin{array}{l}\text { Foot } \\
\text { Height }\end{array}$ & 8.57 & 4.76 & 6 & 8 & $\begin{array}{c}\text { Data } \\
\text { Seragam }\end{array}$ \\
\hline 11 & $\begin{array}{l}\text { Outside } \\
\text { Seating } \\
\text { Range }\end{array}$ & 79.72 & 60.81 & 77 & 66 & $\begin{array}{c}\text { Data } \\
\text { Seragam }\end{array}$ \\
\hline 12 & $\begin{array}{l}\text { Thick } \\
\text { Thigh }\end{array}$ & 18.23 & 7.04 & 17 & 9 & $\begin{array}{c}\text { Data } \\
\text { Seragam }\end{array}$ \\
\hline
\end{tabular}

6. Determine the length of the backrest

To determine the seat back width, the anthropometric data used is the Sitting Shoulder Height (TBD) 5\% percentile minus the Upper Back Height (TPA) 5\% percentile. So it is expected that students who are both small and fat will feel comfortable in using it. Based on the 
measurement results it can be seen that: The seat back width $=48.78-36 \mathrm{~cm}$

7. To determine the slope angle

The authors refer to the research of a thesis conducted by Susylawati, the best slope of the seat back is 1050 . This is because at a slope angle of 1050 it gives less energy consumption than the slope angle another [4].

Table 6. Anthropometric Data Adequacy Test

\begin{tabular}{|c|c|c|c|c|c|c|c|c|}
\hline No & $\begin{array}{c}\text { Anthropometric } \\
\text { Data }\end{array}$ & $\mathrm{N}$ & $\mathrm{k} / \mathrm{s}$ & $\sum X$ & $\sum \mathrm{X} 2$ & $\left(\sum X\right) 2$ & $\mathrm{~N}^{\prime}$ & Remarks \\
\hline 1 & $\begin{array}{l}\text { High } \\
\text { Popliteal }\end{array}$ & 30 & 40 & 1246 & 51794 & 1552516 & 2 & $\begin{array}{c}\text { Data } \\
\text { Cukup }\end{array}$ \\
\hline 2 & $\begin{array}{l}\text { Poplipteal } \\
\text { Butt }\end{array}$ & 30 & 40 & 1297 & 56127 & 1682209 & 2 & $\begin{array}{l}\text { Data } \\
\text { Cukup }\end{array}$ \\
\hline 3 & Width Hip & 30 & 40 & 1337 & 59759 & 1787569 & 5 & $\begin{array}{l}\text { Data } \\
\text { Cukup }\end{array}$ \\
\hline 4 & $\begin{array}{l}\text { Shoulder } \\
\text { Width }\end{array}$ & 30 & 40 & 1180 & 46458 & 1392400 & 2 & $\begin{array}{l}\text { Data } \\
\text { Cukup }\end{array}$ \\
\hline 5 & $\begin{array}{l}\text { Height } \\
\text { Seated Seat }\end{array}$ & 30 & 40 & 1544 & 79542 & 2383936 & 2 & $\begin{array}{l}\text { Data } \\
\text { Cukup }\end{array}$ \\
\hline 6 & $\begin{array}{l}\text { High Back } \\
\text { Up }\end{array}$ & 30 & 40 & 1147 & 43907 & 1315609 & 2 & $\begin{array}{l}\text { Data } \\
\text { Cukup }\end{array}$ \\
\hline 7 & $\begin{array}{l}\text { High Elbow } \\
\text { Sitting }\end{array}$ & 30 & 40 & 649 & 14125 & 421201 & 10 & $\begin{array}{l}\text { Data } \\
\text { Cukup }\end{array}$ \\
\hline 8 & $\begin{array}{l}\text { Elbow } \\
\text { Length to } \\
\text { finger }\end{array}$ & 30 & 40 & 1481 & 73677 & 2193361 & 13 & $\begin{array}{l}\text { Data } \\
\text { Cukup }\end{array}$ \\
\hline 9 & $\begin{array}{l}\text { Length of } \\
\text { Buttock to } \\
\text { Knee }\end{array}$ & 30 & 40 & 1621 & 87991 & 2627641 & 8 & $\begin{array}{l}\text { Data } \\
\text { Cukup }\end{array}$ \\
\hline 10 & Foot Height & 30 & 40 & 200 & 1345 & 40000 & 14 & $\begin{array}{l}\text { Data } \\
\text { Cukup }\end{array}$ \\
\hline 11 & $\begin{array}{l}\text { Outside } \\
\text { Seating } \\
\text { Range }\end{array}$ & 30 & 40 & 2108 & 148410 & 4443664 & 4 & $\begin{array}{l}\text { Data } \\
\text { Cukup }\end{array}$ \\
\hline 12 & Thick Thigh & 30 & 40 & 413 & 4889 & 143641 & 29 & $\begin{array}{l}\text { Data } \\
\text { Cukup }\end{array}$ \\
\hline
\end{tabular}

From table 5 it can be concluded that all data are uniform and from table 6 it is known that the results of the data adequacy test are sufficient data.

\section{Analysis and determination of table dimensions}

1. Determine table height

In determining the size of the table height from the floor using popliteal knee folding dimension anthropometry data (Popliteal Height = TP) $95 \%$ percentile plus Height Sitting (TSD) $95 \%$ percentile. Based on the measurement results it can be seen that:

Table height from the floor $=43.55+21.89=$ $65.44 \sim 66 \mathrm{~cm}$

2. Determine the width of the table

The width of the table is determined by the double quarto paper length by considering the adjustment of the width of the paper for notebooks, textbooks, modules and drawing paper of students. This is also adjusted to the needs of students at the time when class theory, learning takes place, so that the reach of short students' hands feels comfortable and the longer range is still comfortable in using it. Based on the measurement results it can be seen that the size of the double quarto paper is:

Table width $=(2 \times 29,7)=59,4 \sim 60 \mathrm{~cm}$

Table 7. Percentile Calculation Results

\begin{tabular}{|c|c|c|c|c|}
\hline \multirow[b]{2}{*}{ No } & \multirow[b]{2}{*}{$\begin{array}{c}\text { Anthropometric } \\
\text { Data }\end{array}$} & \multicolumn{3}{|c|}{ Percentile } \\
\hline & & $\begin{array}{c}\mathrm{P} 5=\mathrm{x}-1,645 \\
\sigma \mathrm{x}\end{array}$ & $\mathrm{X}$ & $\begin{array}{c}\mathrm{P} 95=\mathrm{x}+1,645 \\
\sigma \mathrm{x}\end{array}$ \\
\hline 1 & High Popliteal & 39.519 & 41.533 & 43.548 \\
\hline 2 & Poplipteal Butt & 40.545 & 44.567 & 48.589 \\
\hline 3 & Width Hip & 29.120 & 33.767 & 38.414 \\
\hline 4 & Shoulder Width & 37.292 & 39.333 & 41.375 \\
\hline 5 & $\begin{array}{l}\text { Height Seated } \\
\text { Seat }\end{array}$ & 48.778 & 51.467 & 54.156 \\
\hline 6 & High Back Up & 36.002 & 38.233 & 40.465 \\
\hline 7 & $\begin{array}{l}\text { High Elbow } \\
\text { Sitting }\end{array}$ & 18.434 & 20.167 & 21.899 \\
\hline 8 & $\begin{array}{l}\text { Elbow Length to } \\
\text { finger }\end{array}$ & 42.106 & 49.367 & 56.628 \\
\hline 9 & $\begin{array}{l}\text { Length of Buttock } \\
\text { to Knee }\end{array}$ & 47.901 & 54.033 & 60.166 \\
\hline 10 & Foot Height & 5.623 & 6.667 & 7.710 \\
\hline 11 & $\begin{array}{l}\text { Outside Seating } \\
\text { Range }\end{array}$ & 65.084 & 70.267 & 75.449 \\
\hline 12 & Thick Thigh & 9.564 & 12.633 & 15.703 \\
\hline
\end{tabular}

3. Determine table length

To determine the length of the table, adjusted to the needs, namely by taking anthropometric data from the Shoulder Width (LB) 95\% percentile plus the width of the folio paper then added tolerance. Tolerance in this case is meant by the assumption that because one table is used by two students, it is necessary to consider the loosening of the movement between the two. Based on the measurement results it can be seen that:

Table Length $=((41,375+21,5) \times 2)+10=(62,875$ x 2$)+10=135.75 \sim 136 \mathrm{~cm}$

4. Determine the footrest

The height of the footrest will be determined using anthropometric data IE the Height of the Foot Eye (TMK) $95 \%$ percentile and multiplied by two. It aims to provide flexibility and comfort in the movement of the soles of the feet. Based on the measurement results it can be seen that the

Height of Footstool $=7.71 \times 2=15.4 \sim 16 \mathrm{~cm}$

5. Determine the length of distance between legs on the table

To determine the length of the distance between the legs on the student desk, the anthropometric data used is the dimension of the Knee Buttock Length (PBL) $5 \%$ percentile multiplied by two, or can be adjusted with the results of the calculation of the length of the design table. Based on the measurement results it can be seen that:

The distance between legs $=47.90 \times 2=95.8 \sim$ $96 \mathrm{~cm}$ or, it can also be made $=124 \mathrm{~cm}$ 
D. Analysis and determination of drawers.

1. To determine the length and width of the drawer, the data used is the length and width of the design table, then divided into two, namely $136 / 2=68 \mathrm{~cm}$ It is intended that in one table there are two drawers, the size of the drawer for each student is $68 \mathrm{~cm}$.

2. Drawer width follows the table width of $65 \mathrm{~cm}$.

3. While the height of the drawer is obtained from the height of the table from under the table, namely Popliteal Height (TP) percentile 5\% + Thigh Thickness (TPa) 5\% percentile.

Table height from below $=39.52+9.56=49.08$ $\mathrm{cm}$

Based on this size, a calculation is performed to determine the height of the drawer that is determined by the mass size of the table height and the minimum height of the table from the bottom of the table, namely:

Drawer Height $=65.44 \mathrm{~cm}-49.08 \mathrm{~cm}=16.36 \mathrm{~cm}$ $=16 \mathrm{~cm}$

Table 8. Results of Comparison of Actual and Design Table and Chair Size

\begin{tabular}{clcc}
\hline $\begin{array}{c}\text { Product } \\
\text { Name }\end{array}$ & Product Sub-Section & $\begin{array}{c}\text { Actual } \\
\text { Size } \\
(\mathrm{cm})\end{array}$ & $\begin{array}{c}\text { Design } \\
\text { Results } \\
(\mathrm{cm})\end{array}$ \\
\hline Chair & - Seat cushion height & 44 & 44 \\
& - Sitting width & 39 & 41 \\
& - Long seat cushion & 40 & 44 \\
& - High seat backs & 48 & 49 \\
& - Wide backrest of chairs & 12 & 13 \\
& - Long backrest & 40 & 42 \\
Table & - Backrest angle & $105^{\circ}$ & $105^{\circ}$ \\
& - Width table & 49 & 60 \\
& - Long table & 118 & 136 \\
& - Desk height & 75 & 66 \\
& - Drawer length & 120 & 136 \\
& - Drawer width & 49 & 60 \\
& - Drawer height & 16 & 16 \\
& - High footrest & 14 & 16 \\
\hline
\end{tabular}

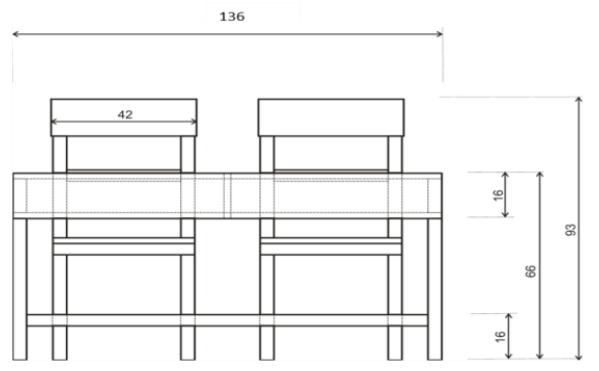

Figure 1. Table and Chair of Front View Design Results

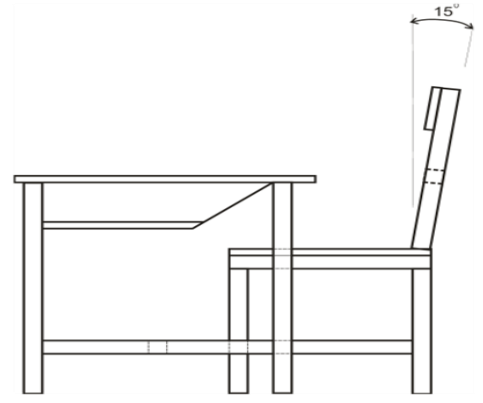

Figure 2. Left-sided Design Results Table and Chair

\section{CONCLUSION}

From the results of the calculations and analysis that the researcher has done, it can be concluded that the width of the sitting mat needs to be increased by $2 \mathrm{~cm}$, the length of the backrest needs to be added by $2 \mathrm{~cm}$, the length of the seat sits need to be added by $4 \mathrm{~cm}$, the length of the table needs to be added $4 \mathrm{~cm}$, the length of the drawer needs to be added $4 \mathrm{~cm}$, the width the table needs to be added by $16 \mathrm{~cm}$, the width of the drawer needs to be added by $16 \mathrm{~cm}$, and the height of the table needs to be reduced by $9 \mathrm{~cm}$, in addition to those in this study does not change the shape of the chair only redesign related to its size.

\section{REFERENCES}

[1] Grandjean, E., Kroemer, K.H.E. Fitting the Task to the Human. A Textbook of Occupational Ergonomics. Fifth Edition. Piladelphie: Taylor 2000.

[2] Nala, N. Penerapan Teknologi Tepat Guna di Pedesaan. Denpasar: Lembaga Pengabdian Kepada Masyarakat Universitas Udayana 1994

[3] Suprapto, Perancangan Kursi Kuliah Yang Ergonomis Di Universitas Veteran Bangun Nusantara Sukoharjo. Laporan Penelitian 2007.

[4] Susylawati, Susy (0023006) Perancangan Kursi Kuliah Ergonomis Yang Memberikan Kenyamanan Dari Segi Konsumsi Energi.Other thesis, Universitas Kristen Maranatha .2005.

[5] Sutajaya, I M.. Perbaikan Kondisi Kerja Mengurangi Beban Kerja dan Gangguan pada Sistem Muskuloskeletal Mahasiswa dalam Menggunakan Mikroskop di Laboratorium Biologi STKIP Singaraja. Majalah Kedokteran Udayana (Udayana Medical Journal) Vol. 32 No. 114. Oktober 2001. 